\title{
Obscuroplaca gen. nov. - a replacement name for Phaeoplaca; Teloschistaceae (lichenized Ascomycota) from the Galapagos Islands
}

\author{
Frank Bungartz ${ }^{1,2,3^{*}}$, Ulrik Søchting ${ }^{4}$ \& Ulf Arup ${ }^{5}$
}

\section{Article info}

Received: 14 Sept. 2021

Revision received: 13 Dec. 2021

Accepted: 16 Dec. 2021

Published: 31 Dec. 2021

Associate Editor

Adam Flakus

\begin{abstract}
A replacement name Obscuroplaca for the illegitimate genus Phaeoplaca is introduced. The three known species are transferred as Obscuroplaca camptidia, O. ochro-
\end{abstract} lechioides, and $O$. tortuca.

Key words: Caloplacoideae, Chrysophyceae, Golden Algae

\section{Introduction}

We recently introduced the name Phaeoplaca Søchting et al., as a new genus in Teloschistaceae (Bungartz et al. 2020). At the time of publication, we were not aware that Chodat et al. (1926) had first proposed an identical name for a genus of freshwater algae in the Chrysophyceae Pascher. The International Code of Nomenclature for algae, fungi, and plants (Turland et al. 2018) applies both to fungi and algae. The name of each taxonomic group governed by the code has to be unique. Therefore, the name Phaeoplaca is an illegitimate later homonym of Chodat's name.

To remedy the situation, we introduce Obscuroplaca as a replacement name here.

Obscuroplaca Søchting, Arup \& Bungartz, nom. nov.

MycoBank MB 841162

Replaced name: Phaeoplaca Søchting, Arup \& Bungartz, Plant and Fungal Systematics 65: 546. 2020, nom. illegit. [ICN (Shenzhen) Art. 53.1].

${ }^{1}$ Biodiversity Integration Knowledge Center, Arizona State University, PO Box 874108, Arizona State University, Tempe, AZ 85287-4108, USA

${ }^{2}$ Charles Darwin Foundation for the Galapagos Islands, Puerto Ayora, Ecuador

${ }^{3}$ Instituto Nacional de Biodiversidad (INABIO), Quito, Ecuador. ORCID: 0000-0002-0717-9264

${ }^{4}$ Section for Ecology and Evolution, Department of Biology, University of Copenhagen, Universitetsparken 15, DK-2100 Copenhagen Ø, Denmark. ORCID: 0000-0001-7122-9425

${ }_{5}^{5}$ Biological Museum, Lund University, Box 117, SE-221 00 Lund, Sweden. ORCID: 0000-0001-6612-8099

* Corresponding author e-mail: frank.bungartz@asu.edu
Non Phaeoplaca Chodat, Bulletin de la Société Botanique de Genève, sér. 2, 17: 210. 1926.

Type: Obscuroplaca camptidia (Tuck.) Søchting et al. (syn. Lecanora camptidia Tuck.).

Etymology: This replacement name is a combination of the syllables '-placa' hinting at Caloplaca (from which species in the genus were transferred), and the Latin '-obscuro' meaning 'dark', referring to the overall dull color of thallus and apothecia, both lacking the typically bright anthraquinones of most other members of the Teloschistaceae.

The following three species were previously included in the genus and are all transferred here into Obscuroplaca.

Obscuroplaca camptidia (Tuck.) Søchting, Arup \& Bungartz, comb. nov.

MycoBank MB 841165

Basionym: Lecanora camptidia Tuck., Proceedings of the American Academy of Arts and Sciences 5: 403. 1862.

Synonym: Phaeoplaca camptidia (Tuck.) Søchting, Arup \& Bungartz, Plant and Fungal Systematics 65: 547. 2020.

Obscuroplaca ochrolechioides (S.Y. Kondr. \& Kärnefelt) Søchting \& Bungartz, comb. nov.

MycoBank MB 841164

Basionym: Caloplaca ochrolechioides S.Y. Kondr. \& Kärnefelt, Bibliotheca Lichenolologica. 106: 180. 2011.

Synonym: Phaeoplaca ochrolechioides (S.Y. Kondr. \& Kärnefelt) Søchting \& Arup, Plant and Fungal Systematics 65: 547. 2020. 
Obscuroplaca tortuca (Søchting \& Bungartz) Søchting \& Bungartz, comb. nov.

MycoBank MB 841163

Basionym: Phaeoplaca tortuca Søchting \& Bungartz, Plant and Fungal Systematics 65: 546. 2020.

\section{Acknowledgements}

We are indebted to James K. Mitchell at Harvard University for notifying us that the name Phaeoplaca had previously been published by Chodat, alerting us to the necessity to propose a replacement name. We also appreciate the support of Konstanze Bensch, Mycobank, in providing guidance to register Obscuroplaca as a replacement name. Robert Lücking and an anonymous reviewer provided constructive criticism how to improve this short manuscript, which we greatly appreciate. And we are indebted to Adam Flakus and Jolanta Miadlikowska, editors of this journal, for facilitating this publication as a short communication. This publication is contribution number 2416 of the Charles Darwin Foundation for the Galapagos Islands.

\section{References}

Bungartz, F., Søchting, U. \& Arup, U. 2020. Teloschistaceae (lichenized Ascomycota) from the Galapagos Islands: a phylogenetic revision based on morphological, anatomical, chemical, and molecular data. Plant and Fungal Systematics 65(2): 515-576. https://doi. org/10.35535/pfsyst-2020-0030

Chodat, R., Raineri, R \& Drew, K. 1926. Algues de la région du Grand St. Bernard III. Bulletin de la Société Botanique de Genève, série II 17: 202-217.

Turland, N. J., Wiersema, J. H., Barrie, F. R., Greuter, W., Hawksworth, D. L., Herendeen, P. S., Knapp, S., Kusber, W.-H., Li, D.-Z., Marhold, K., May, T. W., McNeill, J., Monro, A. M., Prado, J., Price, M. J. \& Smith, G. F. (eds) 2018. International Code of Nomenclature for algae, fungi, and plants (Shenzhen Code) adopted by the Nineteenth International Botanical Congress Shenzhen, China, July 2017. Regnum Vegetabile 159. Glashütten: Koeltz Botanical Books. https://doi.org/10.12705/Code.2018 